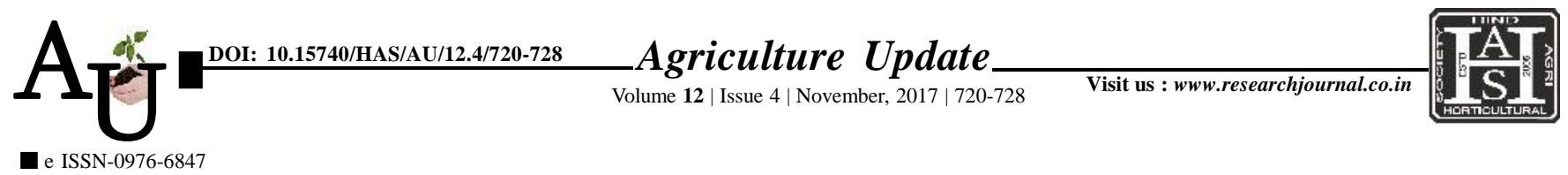

\title{
Rевевсн автіск: Field efficacy of Pseudomonas fluorescens against the cotton aphid, Aphis gossypii Glover (Hemiptera: Aphididae) in Bt and non Bt cotton
}

\author{
T.R. MANJULA, G.S. KANNAN AND P. SIVASUBRAMANIAN
}

Article Chronicle :

Received :

02.09.2017;

Revised :

11.10.2017;

Accepted :

28.10.2017

\section{KeY Words :}

Cotton aphid,

Pseudomonas

fluorescens,

Alternative control,

Bt cotton, Non Bt

cotton
SUMMARY : The cotton aphid, Aphis gossypii Glover (Hemiptera: Aphididae), is a key pest of cotton, irrespective of the use of conventional or organic management. In organic systems, however, the use of synthetic insecticides is not allowed, increasing the difficulty of controlling this pest. This work evaluated aphid control and the ability of products to prevent aphid infestation using entomopathogenic bacteria, Pseudomonas fluorescens compared to a standard synthetic insecticide. The trial was conducted with entomopathogenic fungi, Beauveria bassiana and untreated plants served as the control group. The trial testing the efficacy of $P$. fluorescens in preventing aphid infestation was conducted using the same products. The evaluations were conducted pre and post-treatment of three round of application for the efficacy and the protection against colonization trials, respectively. The lowest aphid populations recorded by the bio inoculant treatment of the soil and foliar application of $P$. fluorescens @ 1\%. Regarding the plant protection against aphid colonization, the insecticide imidacloprid exhibited a better performance compared to the other tested products with steady results over the evaluation period. The other treatments exhibited variable results with protection against aphid colonization throughout the evaluation period.

How to cite this article : Manjula, T.R., Kannan, G.S. and Sivasubramanian, P. (2017). Field efficacy of Pseudomonas fluorescens against the cotton aphid, Aphis gossypii Glover (Hemiptera: Aphididae) in Bt and non Bt cotton. Agric. Update, 12(4): 720-728; DOI : 10.15740/HAS/AU/12.4/720-728.

Author for correspondence :

T.R. MANJULA

Department of

Entomology,

Vanavarayar Institute of Agriculture,

Manakkadavu, POLLACHI (T.N.) INDIA

Email:manjulatr@ gmail.com

See end of the article for authors' affiliations 